\title{
Canadian News
}

\section{RSAC Oral Hearings}

In early May, oral hearings for refugee claimants began in Montreal and Toronto. The hearings, being tried on an experimental basis, are being conducted by the Refugee Status Advisory Committee (RSAC). Separate interviews will be conducted by an RSAC member after claimants are examined under oath by a senior immigration office. That same RSAC member will be present at the under-oath examination. Previously, all recommendations to the Minister were made by the RSAC after it had reviewed transcripts of the examinations conducted by the immigration officer.

The new system is designed to speed up the claims process, to allow claimants to give extra information on the conditions leading up to their claim and to improve the quality of advice that the Minister of Employment and Immigration receives from the Refugee Status Advisory Committee.

\section{Canada Assists Sri Lankans}

Canada's Minister of Employment and Immigration, in a recently announced special humanitarian program for Sri Lankan nationals, relaxed immigrant selection criteria for family members and allowed temporary extensions for visitors.

Effective September 9, nationals of Sri Lanka and Bangladesh will need visas to visit Canada.

\section{Refugee Coalition Seeks Solution}

The Vancouver Coalition with World Refugees has been organized. Its purposes are as follows:

1 . to support "inland refugees", i.e., those persons who have arrived in Canada but whose status is still being determined by Ottawa; (Until this is decided, they cannot obtain work permits, and are dependent on the help provided by friends and refugee agencies.)

2. to organize new sponsorships of refugees now in camps who can gain admittance to Canada if a private sponsorship is forthcoming;

3 . to help those refugees still in camps, and without prospects of being able to return home or to emigrate

4. to organize an adequate publicity campaign i n B.C. communities.

Contact John Conway, Chairman, for further information at $1410 \mathrm{~W}$. 12th Avenue, Vancouver, B.C. V6R 1M8

\section{Personnel Changes}

Kathleen Ptolemy is leaving the InterChurch Committee for Refugees (September 30, 1983) where she has acted as National Refugee Coordinator. She goes to a new position as Refugee Consultant with the Anglican Church of Canada.

Martha Nixon has left her position in CEIC's Refugee Policy Division to become Legislative Assistant to the Minister of Employment and Immigration.

Douglas I. MacDonald ended his contract as Public Information Officer with the Ottawa Branch Office of the UNHCR, effective August 31, 1983. In mid-September, he leaves for Lesotho (southern Africa) to take up duties as a volunteer worker with refugees under the auspices of World University Service of Canada.

Sue Davis left her position as Legal Advisor to the UNHCR in Canada. She recently married and moved to Toronto.

Rick Stainsby left his position as a researcher for the Refugee Status Advisory Committee (RSAC) to join the UNHCR Protection Office in Canberra.
Unaccompanied Children

The Refugee Documentation Project at York University has received funding from the Laidlaw Foundation, CEIC, and the Ontario Ministry of Community and Social Services to study Unaccompanied Children in Emergencies: the Canadian Experience. The Canadian study is part of an international research program initiated by the International Council of Voluntary Agencies in Geneva.

The goal of the Canadian project is to produce a report which documents and analyses legal and placement considerations for the acceptance, care and placement of foreign unaccompanied children brought into Canada from emergency situations in other countries.

The project directors are Professors Howard Adelman and C. Michael Lanphier. Research is being carried out by Catherine May and Lawrence Lam. Professor Diane Pask of the University of Calgary, and Ann Jayne of the Civil Liberties Union, act as consultants on the legal issues.

If you can provide any relevant information or assistance for this study, please contact Catherine May, Project Coordinator, Unaccompanied Children in Emergencies, c/o Refugee Documentation Project, York University, 4700 Keele Street, Downsview, Ontario M3J 2R6. Telephone (416) 667-3639. 